\title{
Research on Dispute Settlement Mechanism of Economic and Trade Cooperation Between China, Mongolia and Russia
}

\author{
Haiyan $\mathrm{Hao}^{1,2}$ \\ ${ }^{1}$ School of Law, Beijing Normal University, Haidian, Beijing, China \\ ${ }^{2}$ School of Law, Inner Mongolia University of Finance and Economics, Hohhot, Inner Mongolia, China \\ Correspondence: Haiyan Hao. E-mail: haohaiyan.1121@163.com
}

This paper is the phased achievement of the Collaborative Innovation Center Project of China-Mongolia-Russia Economic Corridor Project "Research on Dispute Settlement Mechanism of Economic and Trade Cooperation between China, Mongolia and Russia" (ZMEZ201902).

\author{
Received: March 25, $2021 \quad$ Accepted: April 1, $2021 \quad$ Online Published: April 27, 2021 \\ doi:10.5539/ass.v17n5p42 URL: https://doi.org/10.5539/ass.v17n5p42
}

\begin{abstract}
The dispute resolution mechanism of economic and trade cooperation between China, Mongolia and Russia is a kind of dispute resolution mechanism specially used to solve the disputes of economic and trade cooperation between China, Mongolia and Russia. It is not only has the practical necessity, but also has the political and legal feasibility. The main problems of the dispute resolution mechanism are that the dispute resolution methods are too scattered, the dispute resolution basis is too old, and the cohesion and effectiveness of the dispute resolution methods are poor. Under the guidance of the concept of "coordinated development, win-win and mutual benefit, fair procedure, inclusiveness and harmony", it is reasonable to build a dispute resolution mechanism of economic and trade cooperation between China, Mongolia and Russia, which covers the way of political diplomacy and judicial characteristics. Specifically, the dispute resolution mechanism needs to establish special dispute resolution institutions, unified applicable rules, diversified dispute resolution procedures and sound supporting systems.
\end{abstract}

Keywords: China, Mongolia and Russia; Economic and trade cooperation; Dispute resolution mechanism

\section{Introduction}

With the proposal and practice of "the belt and road initiative", "China-Mongolia-Russia Economic Corridor", "Russia's Trans-Eurasian Railway" and "Prairie Silk Road", China-Mongolia-Russia economic and trade cooperation has continued to advance in depth. However, in economic and trade activities, the differences in politics, economy and culture, and the complexity of relations, interests and exchanges have caused complicated disputes in economic and trade cooperation. Complex and diverse economic and trade cooperation disputes between China, Mongolia and Russia need a unified and pluralistic dispute resolution mechanism. At present, the way of dispute resolution is too scattered, the basis of dispute resolution is too old, and the convergence and poor effectiveness of dispute resolution procedures are the main problems in the dispute resolution mechanism of China-Mongolia-Russia economic and trade cooperation. Constructing an effective docking, unified and diversified dispute resolution mechanism is an important guarantee to protect the interests of all subjects in China-Mongolia-Russia economic and trade cooperation. The purpose of this study is to build and improve the dispute resolution mechanism of China-Mongolia-Russia economic and trade cooperation, analyze its necessity and feasibility, summarize its practical difficulties and specific problems, clarify its concept, model and principles, and finally put forward specific countermeasures.

\section{The Necessity and Feasibility}

\subsection{The Necessity}

The economic and trade cooperation between China, Mongolia and Russia has a long history, and the proposal and practice of the "China-Mongolia-Russia Economic Corridor" has upgraded the economic and trade cooperation between China, Mongolia and Russia in depth and breadth. After China, Mongolia and Russia signed the outline of the Plan for the Construction of China-Mongolia-Russia Economic Corridor in 2016, the platform for economic and trade cooperation between China, Mongolia and Russia has been further expanded to 
cover transport infrastructure, port construction, production capacity and investment, and economic and trade cooperation.

With the deepening of economic and trade cooperation, a large number of funds, labor and technology are concentrated in the Sino-Mongolian-Russian economic and trade market, various interest factors are surging, and all kinds of disputes in Sino-Mongolian-Russian economic and trade cooperation are increasingly frequent. According to the statistics of the court department, the number of trade cases received by the courts in Inner Mongolia (mainly cases involving Mongolia and Russia) has increased year by year. Between 2005 and 2009 alone, the number of cases received has more than tripled, from 41 in 2005 to 90 in 2009.The disputes of economic and trade cooperation between China, Mongolia and Russia are breaking through the original state in terms of quantity and characteristics, and the complexity, diversification and uniqueness are becoming more and more prominent. Driven by the highly integrated economic and trade relations, the level of economic and trade cooperation between China and Mongolia and Russia has changed from commodity trade to economic and technological cooperation, and joint ventures have changed from commercial enterprises to productive enterprises. cooperation projects have also gradually changed from small-scale to resource development and large-scale processing industry projects.This is followed by the complexity, diversification and uniqueness of economic and trade cooperation disputes. First of all, the dispute of economic and trade cooperation between China, Mongolia and Russia is becoming more and more complicated. The main body of the dispute is complex, including not only individuals, enterprises, but also the state and government; the causes of disputes are complex, including personal reasons such as infringement and breach of contract, as well as economic, policy, legal and other macro reasons; the nature of disputes is complex, there are not only ordinary commercial disputes, but also international trade disputes, as well as investment cooperation disputes. Secondly, the types of disputes in Sino-Mongolian-Russian economic and trade cooperation show a diversified development trend. With the transformation of the level of economic and trade cooperation, the types of disputes in Sino-Mongolian-Russian economic and trade cooperation have expanded from a single sale contract dispute to a variety of disputes including intellectual property disputes, land use disputes, labor contract disputes, ecological environment disputes and so on. Finally, in addition to complexity and diversification, the dispute over economic and trade cooperation between China, Mongolia and Russia has gradually formed a certain particularity. In terms of types, compared with the heated trade disputes between China and the United States and other developed countries, the economic and trade disputes between China and Mongolia and Russia are mostly commercial disputes and investment disputes, while there are fewer trade disputes between countries. In terms of types, the economic and trade disputes between China and Mongolia and Russia are mainly sales contracts, construction contracts, labor cooperation and other disputes.

In a word, the increasing and complicated disputes in economic and trade cooperation between China, Mongolia and Russia need a unified and diversified dispute resolution mechanism. The construction of a dispute resolution mechanism for Sino-Mongolian-Russian economic and trade cooperation and providing a diversified dispute resolution platform for Sino-Mongolian-Russian economic and trade cooperation is the basic guarantee for promoting people-to-people connection and political mutual trust, and is an inevitable requirement for accelerating trade exchanges and promoting regional economic development.

\subsection{The Feasibility}

\subsubsection{Political Foundation}

The political foundation of mutually beneficial cooperation is the operational premise of the dispute resolution mechanism of China-Mongolia-Russia economic and trade cooperation. In order to safeguard national sovereignty and protect national interests, the construction and implementation of the dispute resolution mechanism of China-Mongolia-Russia economic and trade cooperation must be based on good and mutually beneficial political relations. Adhering to the cooperative spirit of peaceful coexistence, mutual non-aggression and mutual respect, since the formal establishment of diplomatic relations between China and Mongolia and Russia, high-level exchanges have been frequent and a series of political exchanges have been carried out. Up to now, China and Mongolia and Russia have signed many important political treaties and issued many joint statements. At present, an overall political relationship is that China and Mongolia have established a comprehensive strategic cooperative partnership, and China and Russia have been upgraded to a comprehensive strategic cooperative partnership in the new era.

Generally speaking, since the establishment of diplomatic relations between China and Mongolia and Russia, although there have been twists and turns during the period, the cooperative relations between the two sides have been continuously upgraded and are maintaining a good momentum. The political relations of mutual trust and 
mutual benefit, close exchanges and normal development between China and Mongolia and Russia have laid a solid political foundation for the operation of the dispute resolution mechanism of China-Mongolia-Russia economic and trade cooperation.

\subsubsection{Legal Basis}

The feasibility of judicial assistance between China, Mongolia and Russia, especially the feasibility of recognition and implementation of dispute resolution results, is the effective guarantee of the dispute resolution mechanism of China-Mongolia-Russia economic and trade cooperation. China, Mongolia and Russia have joined the international treaties for the purpose of judicial assistance and the judicial assistance treaties signed between China and Mongolia and Russia, which make the dispute resolution mechanism of economic and trade cooperation between China, Mongolia and Russia really fit the original intention of the establishment of the system and realize its entity, procedure and political and economic value. As far as international multilateral treaties are concerned, China, Mongolia and Russia are all members of The New York Convention,which was signed in new york in June 1958, and mainly solves the problems of recognition and enforcement of international commercial arbitration in different countries. According to The New York Convention, every member state should recognize the binding force of the arbitral award and implement it according to the prescribed procedures.

In July 2001, China and Russia signed "the Implementation Outline of the Treaty of Good Neighborliness, Friendship and Cooperation between the People's Republic of China and the Russian Federation", which emphasized that the judicial organs of China and Russia should provide judicial assistance in civil, family, criminal and other cases and improve the legal basis of judicial assistance. In 1992, "the Treaty between the People's Republic of China and the Russian Federation on Judicial Assistance in Civil and Criminal Matters"was signed, which aims to further promote the judicial cooperation between China and Russia. According to the treaty, the two sides assist each other in serving judicial documents and extra-judicial documents, questioning parties, witnesses and experts, conducting identification and inquest, and completing other investigations and evidence collection. In addition, the judgments of the courts of both parties should be recognized and enforced if the conditions are met. In addition to the treaties between the two sides at the national level, in 1996, the China International Chamber of Commerce and the Russian Federation of Trade Unions signed "the Cooperation Agreement on Commercial Arbitration", which encouraged the settlement of disputes arising from or based on contracts between the two sides through arbitration, and affirmed the final effect and enforcement effect of the arbitral award; In addition, the agreement also encourages China and Russia to use their respective potentials to develop mutual cooperation in international arbitration. China and Mongolia also have special bilateral treaties on judicial assistance.

In 1989, China and Mongolia signed "the Treaty between the People's Republic of China and the People's Republic of Mongolia on Judicial Assistance in Civil and Criminal Matters", which aims at developing and strengthening friendly cooperation between the two countries in the judicial field, and becomes the main basis for judicial assistance in civil and commercial matters between the two countries. According to the Treaty, China and Mongolia should provide judicial assistance in economy, marriage and labor, including serving documents, investigating and collecting evidence, requesting and notifying the implementation, etc. "The Medium-and Long-Term Development Outline of China-Mongolia Strategic Partnership"signed by the two countries in 2013 further emphasizes that China and Mongolia should strengthen cooperation in the field of civil and criminal judicial assistance.

\section{Practical Problems}

\subsection{Analysis from the Perspective of Dispute Resolution}

\subsubsection{Litigation Settlement}

Litigation settlement refers to the way in which the law of the country where one of the parties is located is applied in the court of the country where one of the parties is located, and the dispute is resolved by the procedural rules of court trial. China has signed "the Treaty between the People's Republic of China and the Russian Federation on Judicial Assistance in Civil and Criminal Matters"and "the Treaty between the People's Republic of China and the People's Republic of Mongolia on Judicial Assistance in Civil and Criminal Matters". There are no legal obstacles to the delivery of documents, investigation and evidence collection, and execution of judgments. In addition, China has also set up a special international commercial court and formulated the Rules of Procedure of the Supreme People's Court for International Commercial Court (for Trial Implementation), which has become a powerful support for litigation to resolve disputes between China, Mongolia and Russia in economic and trade cooperation. However, there are some problems in the specific 
application: First, litigation settlement is vulnerable to protectionism. For the protection of national interests, the protectionism in economic and trade cooperation is inevitable, which makes it difficult to guarantee the fairness of litigation settlement, and the acceptance of dispute settlement results will be greatly reduced. Second, the dispute resolution procedure is cumbersome and the litigation period is long. Although China and Mongolia and Russia have signed mutual legal assistance treaties, due to their involvement in different countries, each link of service, evidence collection and execution is bound to be more complicated than the procedures within one country, which will affect the litigation cycle. Third, implementation is difficult to guarantee. Execution is the landing link of litigation and the ultimate guarantee of litigation effect. Although there are no legal obstacles, the procedures of transnational enforcement are complicated and the cost is high, so it is difficult to guarantee the legitimate rights and interests of applicants.

\subsubsection{Arbitration Settlement}

Arbitration settlement refers to the way that both parties submit the dispute to a neutral arbitration institution according to the agreement and settle the dispute according to the international commercial arbitration rules. Arbitration has legal basis and realistic basis for settling disputes in economic and trade cooperation between China, Mongolia and Russia. The Treaty on Judicial Assistance in Matters and Criminal Matters signed or acceded by China, Mongolia and Russia, the Convention on the Recognition and Enforcement of Foreign Arbitral Awards and the Cooperation Agreement on Commercial Arbitration signed by the Chamber of Commerce of China and Russia are the legal basis for the arbitration settlement of economic and trade cooperation disputes between China, Mongolia and Russia. China International Economic and Trade Arbitration Commission, Shanghai International Economic and Trade Arbitration Commission, Shenzhen International Arbitration Court and Russia International Commercial Arbitration Court are the realistic basis for arbitration settlement of disputes in economic and trade cooperation between China, Mongolia and Russia. However, in fact, only a few parties are willing to choose arbitration.The reasons can be summarized as follows: First, the lack of professional arbitrators, especially the lack of arbitrators who not only understand international commercial arbitration rules and related professional knowledge, but also understand the legal system and economic and trade cooperation status of China, Mongolia and Russia; Second, the temporary arbitration institution is missing. Compared with the permanent arbitration institution, the temporary arbitration institution is more desirable, efficient and economical. The lack of temporary arbitration institutions makes the advantages of arbitration settlement unable to give full play; Third, property preservation, evidence preservation and property execution are difficult to achieve. Like litigation settlement, arbitration settlement is also affected by complicated procedures, more links and higher costs, which reduces the effectiveness of dispute settlement.

\subsubsection{Mediation Settlement}

Mediation has a long history in China, and it is a dispute resolution system known as "Oriental Experience". Because it is conducted on the basis of consensus between both parties, mediation has the characteristics of strong agreement, flexible way, low cost and easy implementation, which has become an important part of the wave of diversified dispute resolution, and has been widely used at home and abroad, and achieved good practical results. Based on this, quite a few parties are willing to choose mediation in the economic and trade cooperation disputes between China, Mongolia and Russia. It is feasible to settle the economic and trade cooperation disputes between China, Mongolia and Russia through mediation. On one side, China joined the United Nations Convention on International Settlement Agreements Resulted from Mediation in August 2019, which mainly solved the cross-border recognition and enforcement of settlement agreements reached through mediation.On the other side, there are many mediation organizations in China, Mongolia and Russia, such as China International Chamber of Commerce, Russian Chamber of Commerce and Industry, Mongolian Chamber of Commerce and Industry and various branches. The above-mentioned non-profit organizations mainly aim at supporting and encouraging trade and investment activities, which is an important support for mediating and resolving disputes between China, Mongolia and Russia in economic and trade cooperation. However, due to the limited radiation range of mediation organizations, the lack of management and service capabilities, and the lack of professional mediation talents, mediation has not fully played its due role in solving the disputes between China, Mongolia and Russia.

In addition, diplomatic can solve international economic and trade cooperation. Diplomatic consultation settlement has the advantages of peace, friendship, non-confrontation and no harm to the spirit. However, due to the influence of national strength and international relations, dispute settlement is unstable, which can be used as one of the ways of dispute resolution mechanism in China-Mongolia-Russia economic and trade cooperation. How to effectively integrate and link diplomatic consultation with litigation, arbitration and mediation is the key and direction of China-Mongolia-Russia economic and trade cooperation dispute resolution mechanism. 


\subsection{Analysis from the Perspective of Dispute Types}

\subsubsection{The Commercial Disputes.}

The biggest feature of commercial dispute resolution is that both parties can agree on the methods, rules and applicable laws of dispute resolution by contract. Although both parties can choose the way of court trial to solve the dispute, because both parties are unwilling to go to the court of the other country to try and solve the dispute, the court trial has no advantage. From a global perspective, commercial arbitration and mediation attached to it are the main ways to solve ordinary commercial disputes at present. Although China, Mongolia and Russia also have specialized international arbitration institutions and arbitration rules, for example, the influence of Arbitration Rules of China International Economic and Trade Arbitration Commission is gradually increasing, but there is still room for development, which needs to be further promoted. Establishing a special litigation, arbitration and mediation system for commercial disputes in China-Mongolia-Russia economic and trade cooperation is the success or failure of building a dispute resolution mechanism in China-Mongolia-Russia economic and trade cooperation.

\subsubsection{The Trade Disputes.}

Trade disputes between countries generally depend on international treaties. Important trade dispute resolution systems include the World Trade Organization WTO and NAFTA dispute resolution mechanism. At present, the WTO dispute settlement mechanism is a feasible solution to trade disputes between China, Mongolia and Russia. On the one hand, because the WTO dispute resolution mechanism is relatively mature, covering consultation, mediation, adjudication, appeal, enforcement and other links, it can solve disputes more comprehensively; On the other hand, because China, Mongolia and Russia are all members of the World Trade Organization, it is logical to use the dispute resolution mechanism of the WTO. However, there are obvious defects in applying the dispute resolution mechanism of WTO to solve the trade disputes between China, Mongolia and Russia. The WTO dispute settlement mechanism adopts a forward-looking attitude and takes the principle of "treating diseases and saving people". After ruling, if it does violate the treaty, the member States should correct the measures or policies and laws that violate the provisions of the treaty. Otherwise, the winning party can take corresponding revenge after authorization, and the means of retaliation should be advocated in the same field involved. The execution of the whole application for adjudication and retaliation must be carried out in the name of the member States, and the affected enterprises and individuals can not only participate, but also get any compensation from them. In addition, the dispute resolution procedure has a long cycle, and even if a fair adjudication is finally obtained, the losses of enterprises and individuals are huge. Therefore, the incompleteness of dispute resolution has become the biggest problem in the WTO settlement mechanism, and the establishment of a dispute settlement mechanism with effective docking and comprehensive rights protection is an important guarantee to protect the interests of all subjects in China-Mongolia-Russia economic and trade cooperation.

\subsubsection{The Investment Dispute.}

Investment disputes are mainly settled according to investment agreements. With the development of globalization, in order to avoid the infringement of local protectionism in international investment, more and more controversial subjects give up the way of resolving disputes through the courts of the host country, and instead settle investment disputes through investment agreements. The international specialized multilateral investment agreements are mainly" the Convention on Settlement of Investment Disputes between Countries and Nationals of Other Countries"(Washington Convention) and the "North American Free Trade Agreement", and the institutions specializing in settlement of investment disputes are mainly the International Investment Dispute Settlement Center. As China, Mongolia and Russia are all members of the Washington Convention, investment disputes in China-Mongolia-Russia economic and trade cooperation can be settled in the International Investment Dispute Settlement Center by applying ICSID investment dispute settlement mechanism under the Washington Convention. However, due to the fact that most enterprises in China know little about ICSID investment dispute resolution mechanism and lack of practical experience in ICSID arbitration in China, ICSID investment dispute resolution mechanism is seldom used by Chinese investors.

As far as bilateral treaties are concerned, "The Agreement between the Government of the People's Republic of China and the Government of the People's Republic of Mongolia on Encouraging and Mutual Protection of Investment"signed in 1991 and "the Agreement between the Government of the People's Republic of China and the Government of the Russian Federation on Promoting and Mutual Protection of Investment"signed in 2006 are the main basis for the settlement of investment disputes in economic and trade cooperation between China and Mongolia and Russia. According to Article 8 of the"Agreement between the Government of the People's Republic of China and the Government of the People's Republic of Mongolia on Encouragement and Mutual 
Protection of Investment", investment disputes in economic and trade cooperation between China and Mongolia can be settled through diplomatic channels, litigation in the court of the receiving country or arbitration in a special arbitration tribunal, but the third way is limited to disputes involving the collection of compensation amount. According to Article 9 of "the Agreement between the Government of the People's Republic of China and the Government of the Russian Federation on the Promotion and Mutual Protection of Investment", investment disputes in economic and trade cooperation between China and Russia can be settled through diplomatic channels, litigation in the courts of the countries receiving investment, arbitration in the International Center for Settlement of Investment Disputes (ICSID) established by Washington Convention or arbitration tribunal established by Arbitration Rules of UNCITRAL. It can be said that China, Mongolia and Russia have sufficient basis for solving investment disputes in economic and trade cooperation, and they are diverse in many ways, but there are also some shortages in operation. In the case of investment dispute between Heilongjiang International Economic and Technical Cooperation Corporation and Mongolian Government, Heilongjiang International Economic and Technical Cooperation Corporation considered that the Mongolian government's revocation of its mining license violated the bilateral investment protection agreement signed by the two countries, and initiated international investment arbitration. However, because the arbitration matters stipulated in the Agreement between the Government of the People's Republic of China and the Government of the People's Republic of Mongolia on Encouraging and Mutual Protection of Investment were limited to disputes involving the collection of compensation amount, the arbitration tribunal rejected the arbitration on the grounds of "no jurisdiction". The above cases fully show that the relevant investment agreements can not meet the needs of China-Mongolia-Russia economic and trade cooperation and investment dispute resolution under the vision of "the belt and road initiative" and "China-Mongolia-Russia Economic Corridor".

\section{The Concept and Mode Choice}

\subsection{The Concept}

4.1.1 The dispute resolution mechanism of China-Mongolia-Russia economic and trade cooperation should be based on the concept of coordinated development, win-win and mutual benefit, fair procedure, tolerance and harmony. From the purpose of dispute resolution, the foundation and end point of the construction and improvement of dispute resolution mechanism in China-Mongolia-Russia economic and trade cooperation lies in providing a legal environment of good law and good governance for China-Mongolia-Russia economic and trade cooperation, which promotes the sustainable development of China-Mongolia-Russia economic and trade cooperation and promotes the prosperity and development of "China-Mongolia-Russia Economic Corridor" and "the belt and road initiative". Therefore, in the process of constructing the dispute resolution mechanism of China-Mongolia-Russia economic and trade cooperation, the basic idea should be coordinated development and mutual benefit. Specifically, it is to solve disputes as a means and maintain order for the purpose; The process is to check for leaks and fill vacancies, and the result is to improve the system. In short, the dispute resolution mechanism of China-Mongolia-Russia economic and trade cooperation is to resolve economic and trade conflicts, maintain economic and trade order, improve economic and trade system, and provide judicial guarantee for China-Mongolia-Russia economic and trade cooperation.

From the essence of dispute resolution, dispute resolution is a process of restoring justice through dispute resolution procedures. No matter litigation, arbitration, mediation and negotiation, they are all set up for safeguarding rights and interests and realizing justice. However, justice is not static, sticking to the same mathematical formula, and justice will show different features with different contents. As Bodenheimer said, "Justice has a Prooteanface, which is just, equal or harmonious, fickle, can take on different shapes at any time and has a very different appearance. When we carefully looked at this face and tried to unlock the The Secret Behind hiding its surface, we were deeply confused when we joined the club. "Pet-name ruby Therefore, different ways of resolving disputes contain different pursuit of justice. If litigation should take procedural justice as the primary pursuit and reconciliation should take tolerance and harmony as the primary essence, then in the dispute resolution mechanism of China-Mongolia-Russia economic and trade cooperation, the concept of procedural justice and harmonious and inclusive justice should coexist. There are two reasons: First, according to the current basic situation, the dispute resolution mechanism of China-Mongolia-Russia economic and trade cooperation covers litigation, mediation and other dispute resolution methods, which inevitably contain different justice concepts; Secondly, unlike domestic economic disputes, international economic and trade cooperation disputes are more diversified and complex, and the corresponding dispute resolution mechanism should not only guarantee fairness, but also take into account inclusiveness, providing institutional buffer for open, inclusive and developing international economic and trade relations. In a word, the dispute resolution mechanism of China-Mongolia-Russia economic and trade cooperation should take procedural justice, tolerance and harmony 
as its core concept. Procedural justice is to guarantee basic justice elements such as equality and neutrality in dispute resolution process, and inclusive harmony is to enhance the importance of autonomy, consensus and negotiation in dispute resolution process.

\subsection{The Mode Choice}

Due to the influence of economic, political, legal, cultural and other factors, international or regional dispute resolution mechanisms are different. However, looking at different international practices, the dispute resolution mechanisms can be summarized as political diplomacy-oriented mode, judicial-oriented mode, and comprehensive mode of political diplomacy+quasi-justice.

The mode of political diplomacy is to coordinate and solve economic and trade cooperation disputes through diplomatic channels, mainly including consultation, mediation, mediation and good offices. The ASEAN dispute resolution mechanism under the Charter of the Association of Southeast Asian Nations (hereinafter referred to as the ASEAN Charter) encourages the resolution of disputes through political diplomacy. According to Articles 22 and 23 of the ASEAN Charter, member States should resolve all disputes quickly and peacefully through dialogue, consultation and negotiation as much as possible; Member States involved in disputes can reach an agreement at any time through mediation, conciliation and mediation, so as to settle disputes within the time specified in the agreement. Although the ASEAN dispute resolution mechanism introduced arbitration procedure into the original political and diplomatic model in 2010, the political and diplomatic model is still its main way to resolve disputes. The advantage of political diplomacy mode is that it can solve disputes flexibly, and the non-confrontational way of resolving disputes can get more friendly results. The disadvantage is that there are many levels of games and contests in this mode, which easily leads to the deadlock in negotiations, which is protracted and consumes manpower and energy.

The judicial mode is to set up supranational international regional judicial institutions and make binding judgments according to existing rules. According to the "Treaty Establishing the European Economic Community",the European Union has gradually formed a highly judicial dispute resolution mechanism. The judicial mode has been established in the EU dispute resolution mechanism, which has independent judicial organization and strict procedural rules, and its judgment results have direct and highest binding effect on member countries. Compared with the political and diplomatic model, the judicial model has better predictability, stability and higher binding force. However, since the judicial model is related to national sovereignty and judicial jurisdiction, it will undoubtedly challenge the sovereignty of member States, so it is necessary to take the high trust and tolerance of member States as the premise. In addition, the judicial mode, as a rigid way to resolve disputes, will not be conducive to the promotion of harmonious relations among member States if it is mandatory.

Political diplomacy+quasi-judicial mode is one of the most widely used modes. Generally, it is solved through political diplomacy modes such as dialogue, consultation and negotiation, and then submitted to arbitration institutions for arbitration procedures. The arbitration results are binding. Because this mode has certain characteristics of political diplomacy and judicial mode, it is also called comprehensive mode. For example, NAFTA dispute resolution mechanism under North American Free Trade Agreement and CAFTA dispute resolution machine under China-ASEAN Comprehensive Economic Cooperation Framework Agreement are comprehensive models including consultation, mediation, mediation and arbitration procedures. This mode not only provides a platform and opportunity for both parties to the dispute to settle through consultation, but also provides a binding legal guarantee for the settlement of relevant disputes, because it has become a popular mode.

The above models have their own advantages and disadvantages. It needs to be decided by combining the political relations between China, Mongolia and Russia, the level of economic development and the existing basic conditions. With the release of a series of statements such as"the Joint Statement of the People's Republic of China and Mongolia on Deepening the Development of Comprehensive Strategic Partnership"and "the Joint Statement of the People's Republic of China and the Russian Federation on Strengthening Contemporary Global Strategic Stability", and the great ideas such as "the belt and road initiative", "Prairie Silk Road" and "Eurasian Economic Union" put forward one after another, the political and economic relations between China, Mongolia and Russia are getting closer and showing a good trend. However, according to the current situation, China, Mongolia and Russia are far from having the conditions to establish supranational international regional judicial institutions and procedural rules. Therefore, the supranational judicial model is not applicable to the current disputes between China, Mongolia and Russia in economic and trade cooperation. The mode of political diplomacy is more flexible, but because it is greatly influenced by the state power, its predictability and stability are poor, so it is suitable for the treatment of "one case, one discussion", and it is totally dependent on the mode 
of political diplomacy to solve the disputes of China-Mongolia-Russia economic and trade cooperation, which is not conducive to building a pluralistic, stable and lasting dispute resolution mechanism of China-Mongolia-Russia economic and trade cooperation. The comprehensive mode of political diplomacy+quasi-judicature is widely used to solve trade and investment disputes. As mentioned earlier, compared with the political and diplomatic model and judicial model, the comprehensive model is a more reasonable choice model for China-Mongolia-Russia economic and trade cooperation disputes. From the feasibility point of view, this model does not need to be based on strict judicial organization, but can also ensure the consensus of both parties to the greatest extent and maintain the friendly economic and trade relations between China, Mongolia and Russia; From a realistic point of view, at present, China has established the "the belt and road initiative" commercial court, which covers litigation, mediation, arbitration and other procedures, and has the application basis of comprehensive mode.

\section{Conclusion}

\subsection{Setting Up a Special Dispute Resolution Center.}

The establishment of specialized dispute resolution centers will further enhance the popularity, competitiveness and legalization of international regional organizations. Internationally, the international investment dispute settlement center is the first permanent institution specialized in resolving investment disputes between the contracting parties and nationals of other contracting parties. The establishment of the center has greatly enhanced the international influence of the Washington Convention. In fact, in order to promote the long-term development of the "the belt and road initiative", the Supreme People's Court of China has made some explorations and efforts. On June 29, 2018, in order to implement the"Opinions on Establishing the" the belt and road initiative "International Commercial Dispute Settlement Mechanism and Institution",and to solve the "the belt and road initiative" international commercial disputes, the International Commercial Court of the Supreme People's Court, which is located in Shenzhen, Guangdong Province (the first international commercial court) and Xi' an, Shaanxi Province was establishmented. On October 18, 2016, "Beijing Rongshang the belt and road initiative Legal and Commercial Service Center and the belt and road initiative International Commercial Mediation Center" was established. The center aims to solve international commercial or economic and trade disputes in the belt and road initiative through mediation, and it is an important stage for exerting "Chinese experience" and flexibly resolving economic and trade disputes in the belt and road initiative. In addition, a number of "the belt and road initiative" dispute resolution centers are under construction, for example, "the belt and road initiative" International Arbitration Center will be completed in Shanghai

\subsection{Signing a Unified Dispute Resolution Agreement.}

Many international regional organizations have clearly defined dispute settlement rules and applicable laws, such as the Understanding on Dispute Settlement Rules and Procedures based on the World Trade Organization (WTO) and the Agreement on Dispute Settlement Mechanism of China-ASEAN Comprehensive Economic Cooperation Framework Agreement based on CAFATA. At present, China, Mongolia and Russia have signed the Outline of the Plan for Building China-Mongolia-Russia Economic Corridor in 2016. According to the outline, China, Mongolia and Russia will carry out multi-level and in-depth cooperation in the fields of transportation infrastructure, production capacity and investment cooperation and port construction in the future. However, at present, China, Mongolia and Russia have formed a unified dispute settlement agreement oriented to China-Mongolia-Russia economic and trade cooperation, which has to be said to be a shortcoming.

\subsection{Diversified and One-stop Dispute Resolution Procedure.}

With the acceleration and frequency of transactions, there are more and more places where domestic and international interests combine and collide, and disputes become more and more extensive. Diversified dispute resolution procedures have become the product of resolving the pressure of dispute resolution at home and abroad and achieving justice. Looking at the various dispute resolution procedures of international regional organizations, the popularity of the comprehensive model covering political diplomacy and judicial factors is closely related to its diversified dispute resolution procedures. In addition to coping with the pressure of dispute resolution, there are two reasons why China-Mongolia-Russia economic and trade cooperation dispute resolution procedure adopts a diversified comprehensive model: First, it meets the diversified dispute resolution needs of China-Mongolia-Russia economic and trade cooperation. As mentioned earlier, in a broad sense, international economic and trade cooperation disputes include ordinary commercial disputes between enterprises and enterprises or individuals, international trade disputes between countries, and investment disputes between enterprises and host countries. The different subjects and types of the above disputes greatly increase the difficulty of resolving disputes in economic and trade cooperation, and it is inevitable to construct diversified 
dispute resolution procedures to meet different dispute resolution needs; The second is to improve the effectiveness of dispute resolution procedures in China-Mongolia-Russia economic and trade cooperation. The diversified dispute resolution procedure of "soft and hard combination" can not only meet different dispute resolution needs, but also integrate the soft model (consultation, negotiation, mediation) based on "consensus" and "tolerance" with the hard model (arbitration, litigation) based on "rigidity" and "justice" to jointly expand the justice basis of China-Mongolia-Russia economic and trade cooperation dispute resolution procedure, enhance the effectiveness of dispute resolution procedure and boost China and Mongolia.

\subsection{The Perfect Assistance System}

The First, the treaty of assistance should be refined. Take the Treaty on Judicial Assistance in Civil and Criminal Matters between the People's Republic of China and Mongolia as an example. Although the law stipulates that China and Mongolia can exchange legal information, it does not specify specific procedures. In practice, many people will still choose other ways to find out legal information. It is the basic basis for strengthening judicial assistance between China, Mongolia and Russia to sign a more detailed judicial assistance treaty matching with the dispute resolution mechanism of economic and trade cooperation between China, Mongolia and Russia. The second, set up assistance centers. Because of the importance of assistance system, special foreign law identification centers have been set up in Chongqing, Shanghai and other places, which will provide legal application support for the smooth settlement of disputes in international economic and trade cooperation. In order to better cooperate with the implementation of the dispute resolution mechanism of China-Mongolia-Russia economic and trade cooperation, a judicial assistance center can be set up under the China-Mongolia-Russia economic and trade cooperation resolution institution to provide institutional support for simplifying assistance procedures and streamlining assistance procedures. The third, enrich the means of assistance. Abundant assistance means are the basic guarantee of assistance efficiency. In the future, we can try to use information technology and Internet technology to improve the convenience and mutual assistance in document delivery, investigation and evidence collection, legal identification, judgment enforcement, etc., and provide formal support for the dispute resolution mechanism of China-Mongolia-Russia economic and trade cooperation.

\section{References}

Bodenheimer, E. (Ed.), \& Deng, Z. L. (Trans.). (2017). Law Theory - Legal Philosophy and Legal Method (pp. 266-267). Beijing: China University of Political Science and Law Press.

China Trade News. (2017). "Area" will be built in Shanghai international arbitration center - China ccpit. Retrieved from http://www.ccpit.org/Contents/Channel_4131/2017/1128/921980/content_921980.htm

Guan, J. B. (2015). The Mode Selection of China's Regional Trade Dispute Settlement Mechanism in the Context of "One Belt And One Road". Journal of Research on Modern State-owned Enterprises, (8), 21-22.

Hao, H. Y. (2019). Consideration and Promotion of Civil Judicial Assistance in Intellectual Property Rights between China and Mongolia. Journal of Inner Mongolia University of Finance and Economics, (5), 145-149.

Hu, Y. R. (2017). Innovation of China-Mongolia Border Trade Dispute Arbitration Resolution Mechanism under "One Belt And One Road" Strategy. Journal of Modern Communication, (9), 1-3.

Wang, G. G. (2017), Research on the Dispute Settlement System of "One Belt and One Road". Journal of Chinese Law, (6), 56-71.

Xie, W. X. (2018). China-Mongolia-Russia Economic Corridor (p. 94). Beijing, China Economic Press.

$\mathrm{Xu}, \mathrm{R} . \mathrm{X}$. (2011). Bulletin of the overall situation of the trial work of border trade cases in the courts of the whole district. Transcript of speech delivered at the Seminar on Theory and Practice of Border Trade Disputes between China, Mongolia and Russia.

Yin, M. (2018). Legal Risks and Countermeasures of China's Investment in Russia under the "One Belt And One Road" Initiative. Journal of International Business Research, (1), 69-85.

\section{Copyrights}

Copyright for this article is retained by the author(s), with first publication rights granted to the journal.

This is an open-access article distributed under the terms and conditions of the Creative Commons Attribution license (http://creativecommons.org/licenses/by/4.0/). 